OPEN ACCESS

Edited by:

Adolfo Andrade-Cetto

Universidad Nacional Autónoma

de México, Mexico

Reviewed by:

Bin Geng,

Fu Wai Hospital, China

Angel Josabad Alonso-Castro, Universidad de Guanajuato, Mexico

*Correspondence:

Ochuko L. Erukainure

loreks@yahoo.co.uk

${ }^{+}$Shared first authorship

Specialty section: This article was submitted to

Ethnopharmacology,

a section of the journal

Frontiers in Pharmacology

Received: 17 August 2017

Accepted: 04 January 2018

Published: 01 February 2018

Citation:

Erukainure OL, Hafizur RM, Kabir N, Choudhary MI, Atolani O, Banerjee P,

Preissner R, Chukwuma Cl,

Muhammad A, Amonsou EO and Islam MS (2018) Suppressive Effects of Clerodendrum volubile $P$ Beauv. [Labiatae] Methanolic Extract and lts

Fractions on Type 2 Diabetes and lts Complications. Front. Pharmacol. 9:8. doi: 10.3389/fphar.2018.00008

\section{Suppressive Effects of} Clerodendrum volubile P Beauv. [Labiatae] Methanolic Extract and Its Fractions on Type 2 Diabetes and Its Complications

\author{
Ochuko L. Erukainure ${ }^{1,2,3 * t, ~ R a h m a n ~ M . ~ H a f i z u r ~}{ }^{4 t}$, Nurul Kabir ${ }^{5}$, M. Iqbal Choudhary ${ }^{2}$, \\ Olubunmi Atolani, ${ }^{6,7}$, Priyanka Banerjee ${ }^{6}$, Robert Preissner ${ }^{6}$, Chika I. Chukwuma ${ }^{8,9}$, \\ Aliyu Muhammad ${ }^{4,10}$, Eric O. Amonsou ${ }^{8}$ and Md. Shahidul Islam ${ }^{3}$
}

\begin{abstract}
${ }^{1}$ Nutrition and Toxicology Division, Federal Institute of Industrial Research Oshodi, Lagos, Nigeria, ${ }^{2}$ H.E.J. Research Institute of Chemistry, International Center for Chemical and Biological Sciences, University of Karachi, Karachi, Pakistan, ${ }^{3}$ Department of Biochemistry, School of Life Sciences, University of KwaZulu-Natal, Westville Campus, Durban, South Africa, ${ }^{4}$ Dr. Panjwani Center for Molecular Medicine and Drug Research, International Center for Chemical and Biological Sciences, University of Karachi, Karachi, Pakistan, ${ }^{5}$ Faculty of Science, Institute of Biological Sciences, University of Malaya, Kuala Lumpur, Malaysia, ${ }^{6}$ Structural Bioinformatics Group, Institute for Physiology, Charité - University Medicine Berlin, Berlin, Germany, ${ }^{7}$ Department of Chemistry, University of Ilorin, Ilorin, Nigeria, ${ }^{8}$ Department of Food Technology, Durban University of Technology, Steve Biko Campus, Durban, South Africa, ${ }^{9}$ Department of Pharmacology, University of the Free State, Bloemfontein, South Africa, ${ }^{10}$ Department of Biochemistry, Ahmadu Bello University, Zaria, Nigeria
\end{abstract}

Type 2 diabetes is the most prominent of all diabetes types, contributing to global morbidity and mortality. Availability and cost of treatment with little or no side effect especially in developing countries, remains a huge burden. This has led to the search of affordable alternative therapies especially from medicinal plants. In this study, the antidiabetic effect of the methanolic extract, dichloromethane (DCM), butanol $(\mathrm{BuOH})$ and aqueous fractions of Clerodendrum volubile leaves were investigated in type 2 diabetic rats for their effect on glucose homeostasis, serum insulin level and hepatic biomarkers, lipid profile, pancreatic redox balance and $\mathrm{Ca}^{2+}$ levels, and $\beta$-cell distribution and function. The DCM was further fractionated to isolate the active compounds, biochanin and 5,7,4'-trimethoxykaempferol. They were investigated for their toxicity and ADMET properties, $\alpha$-glucosidase and angiotensin I converting enzyme (ACE) inhibitory activities in silico. There were significant $(p<0.05)$ decrease in blood glucose, cholesterol, LDL-C, VLDL-C, triglyceride, AST and ALT levels in all treated groups, with DCM fraction showing the best activity. All treated rats showed significantly $(p<0.05)$ improved anti-oxidative activities. Treatment with the DCM fraction led to significant $(\rho<0.05)$ increased serum insulin and pancreatic $\mathrm{Ca}^{2+}$ levels, as well as improved $\beta$-cell distribution and function. DCM fraction also showed improved glucose tolerance. DCM fraction dose-dependently inhibited ACE activity. The toxicity class of the isolated compounds was predicted to be 5. They were also predicted to be potent inhibitors of cytochrome P (CYPs) 1A2, 2D6 and 3A4. They docked well with $\alpha$-glucosidase and ACE. These results indicate the therapeutic potential of 
the plant against type 2 diabetes, with the DCM fraction being the most potent which may be attributed to the isolated flavones. It further suggests antihypertensive potentials of the DCM fraction. However, inhibition of CYPs by the flavones may suggest caution in usage with other prescribed drugs metabolized by these enzymes.

Keywords: biochanin, Clerodendrum volubile, immunohistochemistry, type 2 diabetes and $5,7,4^{\prime}$-trimethoxykaempferol

\section{INTRODUCTION}

The treatment and management of diabetes mellitus (DM) remains a global health challenge, with developing countries being the most affected. DM is a chronic disease characterized by increased blood glucose due to the pancreatic $\beta$ cells unable to produce insulin as in the case of type 1 diabetes (T1D), or inability of the body to effectively utilize the insulin produced as in the case of type 2 diabetes (T2D) (Erukainure et al., 2013). T2D is recognized as the most prevalent $(\geq 90 \%)$ of the two types, accounting for $12 \%$ of global total health expenditure and five million deaths in 2015 (International Diabetes Federation [IDF], 2015). It mostly occurs as a result of insulin resistance and $\beta$-cell dysfunction, leading to chronic hyperglycemia (Prentki and Nolan, 2006; Cerf, 2013). Increased hyperglycemia triggers excessive production of free radicals, resulting in oxidative stress (Tiwari et al., 2013), which is responsible for the pathogenesis of most diabetic micro- and macro-vascular complications (Constantino et al., 2013).

There is a growing interest in the use of medicinal plants for the treatment as well as management of T2D (Patel et al., 2012; Chikezie et al., 2015). These plants have been employed in folkloric medicine from time immemorial. This has been attributed to their phytochemical constituents with reported anti-oxidative and anti-diabetic activities (Saeed et al., 2012). Moreover, they are readily available and affordable, with lesser side effects as compared to most synthetic antidiabetic drugs. Amongst such plants is Clerodendrum volubile of the Clerodendrum genus.

Often regarded as magic leaf, C. volubile is among the common food ingredients in Southern Nigeria, and also employed in the folkloric treatment of diabetes, ulcer, arthritis, rheumatism, and dropsy (Burkill, 1985; Erukainure et al., 2014). We reported in our previous studies, the anti-oxidative potential of an isolated iridoid glycoside from the leaves in brain and hepatic tissues (Erukainure et al., 2014). We also correlated the antidiabetic potential of the ethyl acetate fraction to the immunomodulatory activity of isolated protocatechuic acid (Erukainure et al., 2017a). We have shown the ability of dietary fatty acids from the leaves to arrest proliferation in human breast cancer cells (Erukainure et al., 2016b). The ability of the leaves extracts to inhibit to $\alpha$-amylase, $\alpha$-glucosidase and angiotensin- 1 converting enzyme has been reported recently (Adefegha and Oboh, 2016). Studies have also demonstrated the ability of the chemical fractions and fatty acids of the flower and stem to modulate phagocytic oxidative burst (Erukainure et al., 2016a, 2017c). Despite these studies, there is still a dearth of information on the effect of the leaves on T2D complications and other compounds that may contribute to its acclaimed antidiabetic properties.

To the best of our knowledge, the isolation and characterization of two flavones, 5,7,4'-trimethoxykaempferol and $4^{\prime}$-methoxy-5,7-dihydroxy isoflavone (biochanin) from the dichloromethane fraction of $C$. volubile leaves methanolic extract has not been reported previously. Thus, the present study also reports the anti-diabetic effects of the chemical fractions of C. volubile leaves in type 2 diabetic rats followed by bioactivity-guided isolation, and structure elucidation of the active compounds. The anti-hypertensive, oral toxicity and drug-like activities of the flavones were also studied in silico.

\section{MATERIALS AND METHODS}

\section{Instrumentation}

${ }^{1} \mathrm{H}$ - and ${ }^{13} \mathrm{C}-\mathrm{NMR}$ spectra (400 and $100 \mathrm{MHz}$, respectively) and two-dimensional correlation spectra COSY, NOSEY, HMQC, and $\mathrm{HMBC}$, were recorded on a Bruker AV-400 spectrometer in $\mathrm{CDCl}_{3} . \delta(\mathrm{ppm})$ values were used for reporting chemical shifts. Hitachi UV-3200 spectrophotometer was used for obtaining the UV spectra. Thin layer chromatography (TLC) was done on precoated silica gel $60 \mathrm{~F}_{254}$ plates (E. Merck, $0.25 \mathrm{~mm}$ ), and detected under UV light $(254 \mathrm{~nm})$ and by spraying with ceric sulfate reagent. The EI-MS (Electron Ionization Mass Spectrometry) spectrum was measured on a JEOL-MSRoute HX 110 mass spectrometer using the standard positive mode.

\section{Plant Materials}

Fresh C. volubile leaves purchased from local farmers at Ifon, Ondo State, Nigeria, were identified and authenticated by Dr. Henry Akinbosun of the Department of Botany, University of Benin, Benin City, Nigeria. It was assigned the voucher number, $\mathrm{UBH}_{\mathrm{C} 284}$ and thereafter deposited at the herbarium. The leaves were air-dried, pulverized to fine powder, and stored in air-tight containers till further analysis.

\section{Extraction and Fractionation}

Four and half (4.5) $\mathrm{kg}$ of the blended sample was subjected to methanol $(\mathrm{MeOH})$ extraction at room temperature. The resulting extract was concentrated in vacuo using Buchi Rotavapor (Model: R-300, Buchi, Switzerland) to yield $450 \mathrm{~g}$ crude extract. One hundred gram $(100 \mathrm{~g})$ of the crude extract was subsequently dissolved in distilled water and further subjected to liquid-liquid fractionation using gradient polarity solvents in the order: $n$ hexane (Hex), dichloromethane (DCM), ethyl acetate (EtOAc) 
and $n$ - butanol (BuOH). The fractions were concentrated in vacuo, while the aqueous residue was freeze dried.

\section{Enzyme Inhibitory Assay}

The methanolic crude extract and fractions were evaluated for their antidiabetic potentials by assaying their inhibitory activities against $\alpha$-glucosidase (Oboh and Ademosun, 2011; Ramsay et al., 2012). Based on the results, the crude extract, $\mathrm{DCM}, \mathrm{BuOH}$, and aqueous fractions were selected for in vivo studies.

\section{Animals}

Forty-two male albino rats of Wistar strain weighing about 180$200 \mathrm{~g}$ from Animal Resource Facility of International Center for Chemical and Biological Sciences (ICCBS), University of Karachi, Karachi, Pakistan, were used for the study. They were acclimatized on standard rat pellet chows for 1 week, with water provided ad libitum under standard laboratory conditions of natural photo period of 12-h light-dark cycle. All animal studies were carried out under the approval and guidelines of the biological ethical committee of the International Center for Chemical and Biological Sciences (ICCBS), University of Karachi, Karachi, Pakistan, in accordance to the Declaration of Helsinki. The protocol approval number is 2015-0020.

\section{Induction of Type 2 Diabetes}

Type 2 diabetes was induced using the streptozotocinnicotinamide model (Erukainure et al., 2017a; Noor et al., 2017). The rats were first intraperitoneally injected with nicotinamide (120 $\mathrm{mg} / \mathrm{kg} \mathrm{bw})$, then $15 \mathrm{~min}$ later with streptozotocin (60 mg/kg bw) intravenously. The control groups were injected with the required volume of citrate buffer and normal saline only.

After 2 weeks, rats were considered diabetic with blood glucose level $>190-200 \mathrm{mg} / \mathrm{dl}$ and used for the study.

\section{Acute Antidiabetic Studies}

Extract and fractions (200 or $400 \mathrm{mg} / \mathrm{kg} \mathrm{bw}$ ) or saline were administered orally to overnight-fasted diabetic rats. Glibenclamide (GB) was used as a positive control. Blood was taken immediately before $(0-\mathrm{h})$ and at 1-, 2-, and 3-h after extract/GB treatment. Based on the results obtained, $400 \mathrm{mg} / \mathrm{kg}$ bw was selected as the effective dose.

\section{Experimental Design}

The rats were divided into seven groups, each consisting of six animals.

Group 1 - Normal rats + Pelletized rat chows

Group 2 - Diabetic (Untreated)

Group 3 - Diabetic + C. volubile crude extract $(400 \mathrm{mg} / \mathrm{kg} \mathrm{bw})$ Group 4 - Diabetic + C. volubile DCM fraction (400 mg/ kg bw)

Group 5 - Diabetic + C. volubile $\mathrm{BuOH}$ fraction (400 mg/ kg bw)

Group 6 - Diabetic + C. volubile aqueous fraction (400 mg/ $\mathrm{kg} \mathrm{bw)}$

$\mathrm{GB}$ - Diabetic + Glibenclamide (5 mg/kg bw)
The extract dose was selected based on previous studies (Erukainure et al., 2017a). Food and water intake, as well as body weight were monitored daily for each rat. While their blood glucose levels were monitored on weekly basis with a glucometer (Accu-Chek). Treatment lasted for 3 weeks. At the end of the experiment, the rats were subjected to overnight fasting and anesthetized with sodium thiopental $(60 \mathrm{mg} / \mathrm{kg})$, then humanely sacrificed.

\section{Serum Preparation}

Blood was collected via cardiac puncture and centrifuged at $3000 \mathrm{rpm}$ for $10 \mathrm{~min}$. Serum was separated, aliquoted and stored at $-80^{\circ} \mathrm{C}$ for further biochemical assays. The ultra-sensitive rat insulin ELISA kit (Crystal chemicals, Downers Grove, IL, United States) was used in determining the serum insulin level.

$\beta$-Cell function was quantified via the homeostatic model assessment (HOMA)-CIGMA software.

\section{Determination of Hypolipidemic Activities}

Commercial assay kits from Randox ${ }^{\circledR}$ Laboratories, United Kingdom, was used in the determination of serum total cholesterol (TC), triglyceride (TG), and high density lipoprotein (HDL) by colorimetric method according to manufacturer's protocol. The concentration of low-density lipoprotein (LDL) cholesterol and very low-density lipoprotein (vLDL) cholesterol were calculated by the following formula (Friedewald et al., 1972).

\section{Determination of Hepatic and Renal Function Enzymes}

Serum hepatic and renal biomarkers which covers for aspartate transaminase (AST), alanine transaminase (ALT) and urea were analyzed using commercial kits from Randox ${ }^{\circledR}$ Laboratories, United Kingdom, according to the manufacturer's protocol.

\section{Preparation of Pancreatic Tissue Homogenate}

Pancreatic organs collected from the sacrificed rats, were washed in distilled water to remove blood. They were chopped, homogenized in phosphate buffer $(20 \mathrm{mM}$; $\mathrm{pH}$ 6.6) and centrifuged at $10,000 \mathrm{rpm}$ for $15 \mathrm{~min}$ at $4^{\circ} \mathrm{C}$. The supernatant was collected, and stored at $-20^{\circ} \mathrm{C}$ for subsequent analysis.

The protein contents of the tissue homogenates were determined by Lowry's method using bovine serum albumin (BSA) as standard (Lowry et al., 1951).

\section{Determination of Oxidative Stress Parameters}

The serum and pancreatic homogenates were assayed for reduced glutathione (GSH) level (Ellman, 1959), catalase and superoxide dismutase (SOD) activities (Chance and Maehly, 1955; Kakkar 
et al., 1984), and lipid peroxidation (LPO) (Chowdhury and Soulsby, 2002).

\section{Determination of Calcium Ion}

The calcium ion levels of the pancreatic tissue homogenates were quantified using the Cobas kits and Roche/Hitachi 912 automatic analyzer according to manufacturer's protocols, with absorbance read at $450 \mathrm{~nm}$.

\section{Immunohistochemistry}

Pancreases were fixed in neutral buffered formalin solution for overnight and embedded in paraplast. Each piece of pancreatic tissue was serially sectioned $(5 \mu \mathrm{m})$ throughout its length. Six sections in different planes of pancreatic tissues from each group were triple stained for insulin, glucagon and nuclei as previously described (Hafizur et al., 2011, 2012). The fluorescent images were visualized in DAPI, fluorescein isothiocyanate and TxRed channels using Nikon TE2000E fluorescent microscope equipped with a Nikon DS-2MBWc camera. NIS-Elements image analysis software AR 3.0 (Nikon) was used in attaining the images. The images were processed with Adobe Photoshop CS2.

\section{Oral Glucose Tolerance Test with DCM Fraction in Diabetic Rats}

Based on the in vivo studies, the DCM fraction was used for oral glucose tolerance test (OGTT). Twenty four type 2 diabetic rats were divided into four groups consisting of six animals each as shown below:

Group 1: Distilled water

Group 2: $400 \mathrm{mg} / \mathrm{kg}$ DCM fraction

Group 3: $400 \mathrm{mg} / \mathrm{kg}$ crude extract

GB: Glibenclamide $(5 \mathrm{mg} / \mathrm{kg})$ treated rats

They were fasted overnight before the test. Groups 2 and 3 were administered crude extract and DCM fraction, respectively, $30 \mathrm{~min}$ prior to $3 \mathrm{~g} / \mathrm{kg}$ glucose administration. Rats (GB) were treated with $5 \mathrm{mg} / \mathrm{kg}$ glibenclamide $30 \mathrm{~min}$ prior glucose load and used as a positive control. Blood glucose levels of all rats were measured at $-30,0,30,60$, and 120 min after administration.

\section{Angiotensin 1 Converting Enzyme (ACE) Inhibition Assay}

The ability of DCM fraction to inhibit ACE activity was determined spectrophotometrically by estimating the amount of hippuric acid released from hippuryl-histidyl-leucine substrate upon ACE catalysis (Oboh et al., 2013).

\section{Isolation of Compounds from DCM Fraction}

The DCM fraction was subjected to further fractionation using a gravity column chromatography loaded with silica gel. The column was eluted with mixtures of Hex and DCM (95:5) in increasing order of polarity up to 80:20. Elutes were collected and their purity ascertained by subjecting to thinlayer chromatography on pre-coated silica gel $60 \mathrm{~F}_{254}$ sheets and viewed under UV light (254 nm) after spraying with ceric sulfate reagent.

\section{In Silico ADME and Oral Toxicity Prediction of Isolated Compounds}

In silico prediction of ADME properties and oral toxicity vis-à-vis qualitative structure activity relationship (QSAR) and virtual molecular structure activity relationship studies (SARs) of the isolated compounds were carried out using SwissADME (Daina et al., 2017) and ProTOX (Drwal et al., 2014).

\section{In Silico Prediction of Molecular Targets of Isolated Compounds}

The molecular targets for the isolated compounds were predicted using mode of action (MOD) function of the SuperNatural II database (Banerjee et al., 2014). A total of 10 molecular targets were predicted, only prediction above 80 percent accuracy was considered for further validation.

\section{Computational Docking Studies}

The isolated compounds were docked against crystal structure of Human Angiotensin Converting Enzyme (PDB ID: 1O86) and Crystal structure of the N-terminal Subunit of Human Maltase-Glucoamylase Enzyme (PDB ID: 2QMJ) using the Gold version 5.2. The structures of biochanin (PubChem CID: 5280373) and 5,7,4'-trimethoxykaempferol were obtained from NCBI Pubchem database. All the protein molecules were prepared by removing water molecules and hydrogen atoms added. The bioactive conformation of the ligand was used to validate conformation and also define the binding site of the protein (Kitamura et al., 2008) respectively. GOLDScore scoring functions were used to perform all molecular docking runs, while other parameters were used as default. During the docking process a maximum of 300 different conformations was considered for the ligands. The top ten conformers based on highest binding score were used for visual inspections and further analysis. PyMOL was used to visually inspect the docked conformations and the one which had the highest ligand-receptor interactions was selected for further validation. For the Human MaltaseGlucoamylase Enzyme docking, a crystal structure of the protein bound with Acarbose (PDB code: 2QMJ) was used as the receptor molecule. Binding site was defined by removing the acarbose with the radius of $10 \AA$. The original ligand was docked into the protein molecule in order to reproduce the original interactions observed in the crystal complex as well as to design the standard molecular docking protocol.

\section{Statistical Analysis}

Results were expressed as mean \pm Standard Deviation (SD). Differences among groups were analyzed by one-way analysis of variance (ANOVA) using Statistical Package for Social Sciences (SPSS) software, SPSS Inc., Chicago, IL, United States, Standard version 10.0.1. To compare data within group, paired $t$-test 
(2-tailed) was performed. $P$-values $<0.05$ were considered statistically significant for differences in mean using the least of significance difference.

\section{RESULTS}

In vitro $\alpha$-glucosidase inhibitory activity revealed that DCM fraction significantly $(p<0.05)$ inhibited $\alpha$-glucosidase activity as depicted in Figure 1. BuOH and aqueous fractions also showed significant $(p<0.05)$ inhibitory activities. The inhibition by DCM fraction was comparable to acarbose, a standard inhibitor for $\alpha$-glucosidase.

During the acute experimental period (3-h), little or no changes in blood glucose level were observed in non-diabetic control rats, and untreated diabetic rats (Supplementary Figure S1). Interestingly, after oral administration to diabetic rats, $\mathrm{MeOH}, \mathrm{DCM}, \mathrm{BuOH}$, and aqueous fractions of Clerodendrum volubile showed different degree of blood glucose lowering effects. $\mathrm{MeOH}$ significantly decreased the blood glucose levels in a dose-dependent manner, with a significant $(p<0.05)$ reduction at $2-\mathrm{h}$ after treatment with $200 \mathrm{mg} / \mathrm{kg}$ bw. No further improvement was observed after this time period. In sharp contrast, treatment with $400 \mathrm{mg} / \mathrm{kg}$ bw $(\mathrm{MeOH})$ decreased the blood glucose level dramatically at 2-h, with similar results observed at 3 -h after oral administration. In the case of DCM fraction, significant $(p<0.05)$ reduced blood glucose level was attained at 1-h with the dose of $200 \mathrm{mg} / \mathrm{kg}$ bw, and more significant reductions at 2 - and 3 -h. Treatment with $400 \mathrm{mg} / \mathrm{kg}$ bw showed more pronounced effect on blood glucose lowering effects. In the case of $\mathrm{BuOH}$ fraction, treatment with $200 \mathrm{mg} / \mathrm{kg}$ bw showed little or no effects. However, treatment with $400 \mathrm{mg} / \mathrm{kg}$ bw showed significant $(p<0.05)$ reduction in blood glucose level at 2-h. No further improvement was observed after this time period. For the aqueous fraction, both doses showed significant $(p<0.05)$ reduction in blood glucose level at 2 -h. while the standard drug significantly $(p<0.05)$ lowered the blood glucose in a time-dependent manner.

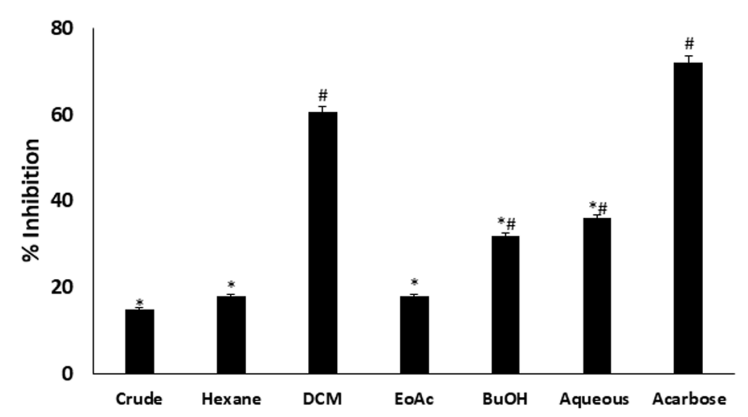

FIGURE 1 | Inhibitory effect of $C$. volubile methanolic extract and fractions on $\alpha$-glucosidase activity. Data $=$ mean $\pm S D ; n=3$. *Statistically significant $(p<0.05)$ compared to Acarbose; " statistically significant $(p<0.05)$ compared to crude extract. Crude, crude extract; Hexane, hexane fraction; DCM, dichloromethane fraction; EoAC, ethyl acetate fraction; $\mathrm{BuOH}$, butanol fraction; Aqueous, aqueous fraction.
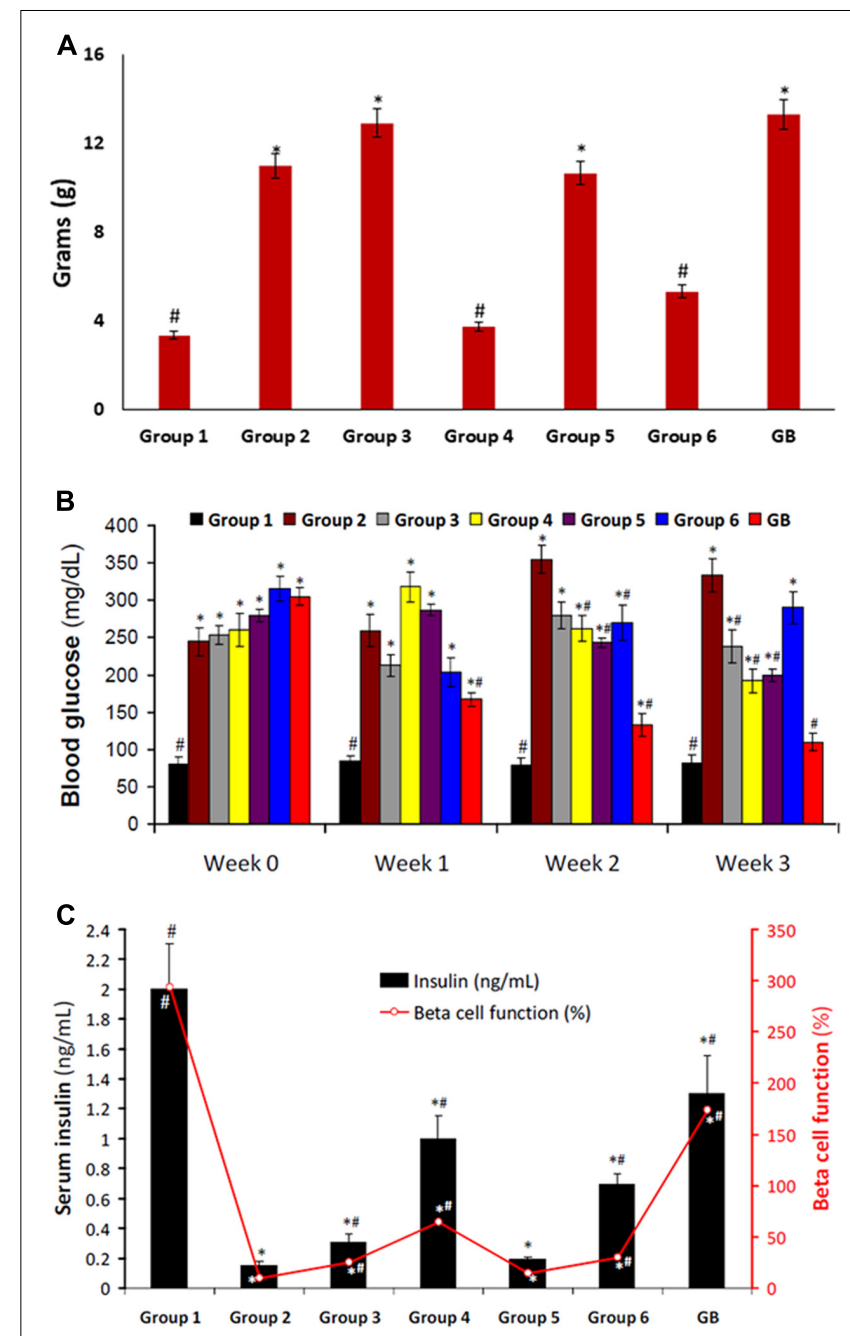

FIGURE 2 | (A) Body weight gain of experimental groups. Data = mean $\pm S D$; $n=6$. "Statistically significant $(p<0.05)$ compared to group 2 ; *statistically significant $(p<0.05)$ compared to group 1. Group 1: normal control; Group 2 diabetic control; Group 3: diabetic rats + crude extract; Group 4: diabetic rats + dichloromethane fraction; Group 5: diabetic rats + butanol fraction; Group 6: diabetic rats + aqueous fraction; GB: diabetic rats + glibenclamide. (B) Blood glucose level of experimental groups. Data = mean $\pm S D ; n=6$. "Statistically significant $(p<0.05)$ compared to group 2 ; * statistically significant $(p<0.05)$ compared to group 1. Group 1: normal control; Group 2: diabetic control; Group 3: diabetic rats + crude extract; Group 4: diabetic rats +

dichloromethane fraction; Group 5: diabetic rats + butanol fraction; Group 6: diabetic rats + aqueous fraction; GB: diabetic rats + glibenclamide. (C) Serum Insulin level and $\beta$-cell function of experimental groups. Data $=$ mean $\pm S D$; $n=6$. " Statistically significant $(p<0.05)$ compared to group 2 ; *statistically significant $(p<0.05)$ compared to group 1. Group 1: normal control; Group 2: diabetic control; Group 3: diabetic rats + crude extract; Group 4: diabetic rats + dichloromethane fraction; Group 5: diabetic rats + butanol fraction;

Group 6: diabetic rats + aqueous fraction; GB: diabetic rats + glibenclamide.

Induction of T2D led to significant $(p<0.05)$ weight gain as observed in group 2 (Figure 2A). Only rats treated with DCM fraction showed significant $(p<0.05)$ weight reduction. The others showed little or no reduction. Glibenclamide treated group also showed body weight gain. 


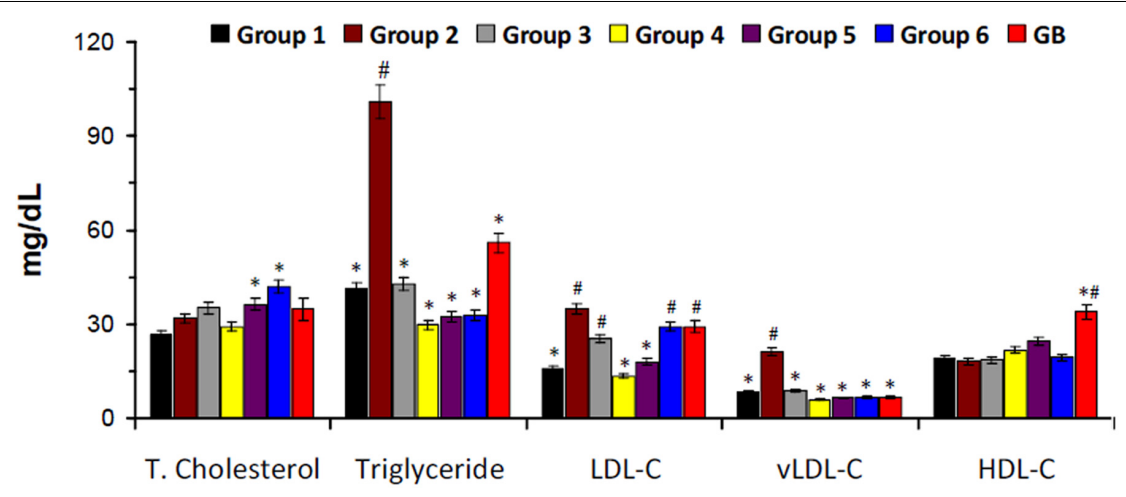

FIGURE 3 | Serum lipid profile of experimental groups. Data = mean $\pm S D ; n=6$. * Statistically significant $(p<0.05)$ compared to group 2 ; * statistically significant ( $p<0.05)$ compared to group 1. Group 1: normal control; Group 2: diabetic control; Group 3: diabetic rats + crude extract; Group 4: diabetic rats +

dichloromethane fraction; Group 5: diabetic rats + butanol fraction; Group 6: diabetic rats + aqueous fraction; GB: diabetic rats + glibenclamide.

Induction of T2D also led to significant $(p<0.05)$ increased blood glucose level, and decreased serum insulin level and $\beta$-cell function as depicted in Figures 2B,C, respectively. These were significantly $(p<0.05)$ reversed in rats treated with DCM fraction. $\mathrm{BuOH}$ fraction-treated rats also showed significant glucose reduction with concomitant increased serum insulin level. Although the crude extract and aqueous showed nonsignificant reduction of blood glucose level, however, serum insulin level was significantly increased. $\beta$-Cell function was dramatically decreased in the control diabetic rats. However, $\beta$-cell function was increased significantly in the crude extract, dichloromethane and aqueous fractions treated rats. The standard drug glibenclamide also improved serum insulin and $\beta$-cell function significantly.

There was a slight increase in serum total cholesterol level in the untreated diabetic rats (group 2) as depicted in Figure 3. However, the levels of triglyceride, LDL-C, and vLDL-C were significantly higher in untreated diabetic rats. Treatment with $\mathrm{DCM}$ and $\mathrm{BuOH}$ fractions caused significant $(p<0.05)$ decrease of their levels. Significant $(p<0.05)$ decreased triglyceride and vLDL-C levels were also observed in groups treated with the crude extract and aqueous fraction. There was no significant difference in the HDL-C levels in the crude extract or its fractiontreated groups. The positive control glibenclamide significantly lowered total cholesterol, triglyceride, LDL-C, and vLDL-C levels and elevated HDL-C level.

There was a significant increase in serum ALT level on induction of T2D as shown in Figure 4A. Serum AST level was also increased but was not significant. Treatment with the crude extract, DCM and $\mathrm{BuOH}$ fractions significantly $(p<0.05)$ decreased ALT level. DCM fraction also caused a significant $(p<0.05)$ decrease in AST level. Treatment with aqueous fraction significantly $(p<0.05)$ increased both enzyme levels. Induction of T2D led to little or no significant increase in serum urea level. However, significantly higher $(p<0.05)$ levels were observed in rats treated with $\mathrm{BuOH}$ and aqueous fractions (Figure 4B).

There was significant $(p<0.05)$ decrease in pancreatic GSH level, SOD and catalase activities as depicted in Table 1. There was no significant difference in serum GSH level and catalase activity.
MDA levels were significantly $(p<0.05)$ increased in both serum and pancreatic tissues. These were significantly $(p<0.05)$ reversed in the treated groups.

There were significant $(p<0.05)$ increases in pancreatic $\mathrm{Ca}^{2+}$ levels in all treated groups, with DCM fraction showing the highest level as shown in Figure 5.

Immunohistochemistry analysis of pancreas revealed an even distribution of $\alpha$ - and $\beta$-cells throughout the pancreatic islets of normal rats (group 1), with the $\beta$-cells in abundance and more concentrated in the islets core while the $\alpha$-cells in the periphery of $\beta$-cells as depicted in Figure 6. The $\beta$-cells were significantly deteriorated in the untreated diabetic rats (group 2) with increased number of $\alpha$-cells compared to the normal rat. However, treatment with the crude extract and fractions led to an increment in the number and size of the $\beta$-cells. This was more pronounced in the crude extract (group 3) and DCM (group 4) treated rats. Glibenclamide treatment also significantly modulated $\beta$-cells size as well number. Predominant $\beta$-cells hypertrophy was observed in the glibenclamide-treated diabetic rats as shown in GB group.

OGTT assay revealed an attained peak level for all groups at $30 \mathrm{~min}$ after glucose administration as shown in Figure 7. The crude extract treated rats (group 3) showed significant $(p<0.05)$ improved glucose tolerance compared to the untreated diabetic rats (group 1). Administration of DCM led to significant reduction in glucose intolerance in diabetic rats (group 2). Glibenclamide significantly improved the glucose tolerance in all the time points compared to the untreated diabetic rats.

DCM fraction showed significant $(p<0.05)$ and dosedependent inhibitory activity on ACE, which compared favorably to the standard drug used as evident by the $\mathrm{IC}_{50}$ values (Figure 8).

$4^{\prime}$-methoxy-5,7-dihydroxy isoflavone (Biochanin) was obtained from elution with Hex and DCM (85:15) and shown in Figure 9A. EIMS m/z $284[\mathrm{M}+\mathrm{H}]^{+}, 284$ (100), 241 (27), 236 (14), 152 (19), 132 (41), 71 (31). ${ }^{1} \mathrm{H}-\mathrm{NMR}\left(500 \mathrm{MHz}, \mathrm{CH}_{3} \mathrm{COCH}_{3}, \delta\right.$, ppm) $\delta 13.0(1 \mathrm{H}, \mathrm{s}, \mathrm{OH}), 8.01\left(1 \mathrm{H}, \mathrm{s}, \mathrm{H}-2^{\prime}\right), 7.53\left(2 \mathrm{H}, \mathrm{d}, \mathrm{H}-2^{\prime}, 6^{\prime}\right)$, $7.12\left(2 \mathrm{H}, \mathrm{d}, \mathrm{H}-3^{\prime}, 5^{\prime}\right), 7.10$ (1H, d, H-8), $6.64(1 \mathrm{H}, \mathrm{d}, \mathrm{H}-6), 3.90$ $\left(3 \mathrm{H}, \mathrm{s}, \mathrm{OCH}_{3}\right)$. The data were compared with literature (Du et al., 2006; Fokialakis et al., 2012). 

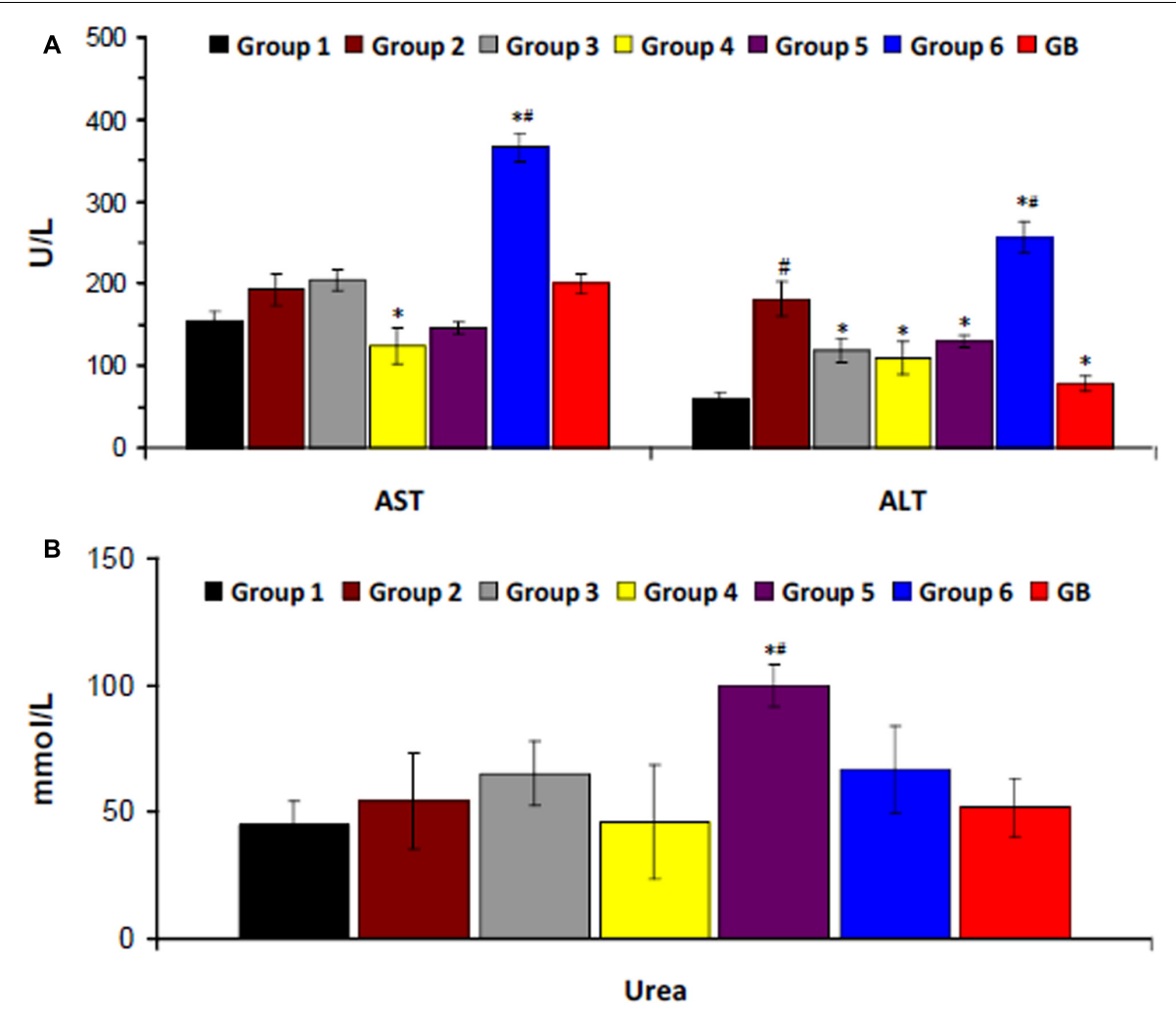

FIGURE 4 | Serum (A) hepatic and (B) renal biomarkers of experimental groups. Data = mean $\pm S D ; n=6$. *Statistically significant $(p<0.05)$ compared to group 2; \# statistically significant $(p<0.05)$ compared to group 1. Group 1: normal control; Group 2: diabetic control; Group 3: diabetic rats + crude extract; Group 4: diabetic rats + dichloromethane fraction; Group 5: diabetic rats + butanol fraction; Group 6: diabetic rats + aqueous fraction; GB: diabetic rats + glibenclamide.

TABLE 1 | Antioxidant activities in experimental groups.

\begin{tabular}{|c|c|c|c|c|c|c|c|c|}
\hline \multirow[t]{2}{*}{ Groups } & \multicolumn{2}{|c|}{ GSH (mol/L) } & \multicolumn{2}{|c|}{ SOD (U/mg protein) } & \multicolumn{2}{|c|}{ Catalase (U/mg protein) } & \multicolumn{2}{|c|}{ MDA (mol/L) } \\
\hline & Serum & Pancreas & Serum & Pancreas & Serum & Pancreas & Serum & Pancreas \\
\hline Group 1 & $0.57 \pm 0.01$ & $91.82 \pm 5.08^{*}$ & $21.03 \pm 1.40^{*}$ & $40.09 \pm 0.99^{*}$ & $55.22 \pm 1.00$ & $121.91 \pm 9.45^{*}$ & $211.86 \pm 8.99 *$ & $314.97 \pm 10.84^{*}$ \\
\hline Group 2 & $0.49 \pm 0.03$ & $78.27 \pm 6.99^{\#}$ & $16.13 \pm 0.99^{\#}$ & $27.21 \pm 0.57^{\#}$ & $49.46 \pm 1.05$ & $74.65 \pm 2.08^{\#}$ & $276.84 \pm 9.04^{\#}$ & $1011.30 \pm 18.35^{\#}$ \\
\hline Group 3 & $0.53 \pm 0.01$ & $85.05 \pm 9.54$ & $17.39 \pm 2.88^{\#}$ & $31.57 \pm 1.86^{\#}$ & $60.11 \pm 3.59 *$ & $101.73 \pm 7.53^{*}$ & $218.93 \pm 10.38^{*}$ & $861.58 \pm 14.59^{* \#}$ \\
\hline Group 4 & $0.55 \pm 0.02$ & $88.11 \pm 5.03$ & $21.30 \pm 2.99^{*}$ & $35.92 \pm 0.84^{*}$ & $72.00 \pm 3.99^{* \#}$ & $104.32 \pm 8.02^{*}$ & $234.46 \pm 20.92^{*}$ & $649.72 \pm 20.33^{* \#}$ \\
\hline Group 5 & $0.59 \pm 0.07$ & $94.16 \pm 5.11^{*}$ & $20.29 \pm 1.72^{*}$ & $30.58 \pm 1.05^{\#}$ & $46.76 \pm 3.89$ & $96.68 \pm 3.05^{*}$ & $211.86 \pm 10.99^{*}$ & $475.99 \pm 10.38^{* \#}$ \\
\hline Group 6 & $0.55 \pm 0.03$ & $87.47 \pm 5.90$ & $16.98 \pm 1.45^{\#}$ & $30.51 \pm 0.78^{\#}$ & $55.02 \pm 1.02$ & $109.32 \pm 4.06^{*}$ & $220.34 \pm 12.87^{*}$ & $890.44 \pm 21.30^{* \#}$ \\
\hline
\end{tabular}

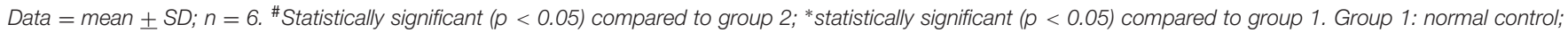

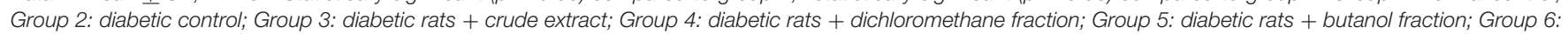
diabetic rats + aqueous fraction.

5,7,4'-trimethoxykaempferol was also obtained from elution with Hex and DCM (82:7.5) and shown in Figure 9B. EIMS m/z

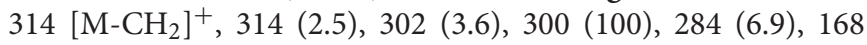
(43.2), 133 (15.6), 69 (18) and 44 (72.3). ${ }^{1} \mathrm{H}-\mathrm{NMR}(400 \mathrm{MHz}$, $\left.\mathrm{CH}_{3} \mathrm{COCH}_{3}, \delta, \mathrm{ppm}\right) \delta 12.86(1 \mathrm{H}, \mathrm{s}, \mathrm{OH}), 7.99-8.03(2 \mathrm{H}, \mathrm{dd}$, $\left.J=8.8 \mathrm{~Hz}, \mathrm{H}-2^{\prime}, 6^{\prime}\right), 7.09-7.13\left(2 \mathrm{H}, \mathrm{dd}, J=8.8 \mathrm{~Hz}, \mathrm{H}-3^{\prime}, 5^{\prime}\right), 6.65$ (2H, s, H-6, H-8), $3.90\left(9 \mathrm{H}, \mathrm{s}, 5,7,4^{\prime} \mathrm{OCH}_{3}\right)$.

Based on the predictions both compounds biochanin and $5,7,4^{\prime}$-trimethoxykaempferol were classified under the toxicity class, V (Table 2), which corresponds to non-toxic class. Their GI absorption was predicted to be high. They were both predicted to be inhibitors of CYP1A2, CYP2D6, and CYP3A4. Biochanin was predicted to be able to cross the blood brain barrier (BBB).

From the molecular docking results, both compounds, 5,7,4'-trimethoxykaempferol and Biochanin bonded to the active site of the ACE (Supplementary Figure S2A). From the ligand-receptor interaction, 5,7,4'-trimethoxykaempferol interacts with the active site of the ACE, forming hydrogen bond with the residues HIS 387, TYR 523, LYS 511. Similarly, Biochanin interacts with the residues HIS 383, GLU 411, HIS 387, TYR 523 (Supplementary Figure S2B). These interactions are similar to that observed with the original ligand Lisinopril. The 


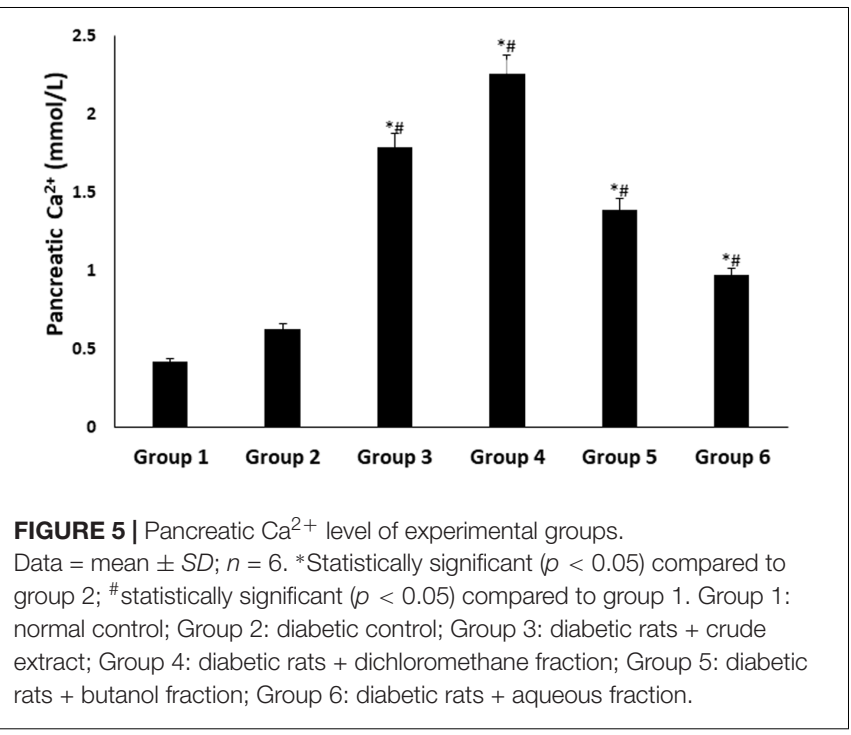

information collected from the docking experiment of the two compounds correlated with the results obtained from the in vitro ACE inhibition assay.

Also from the molecular docking results, both compounds, $5,7,4^{\prime}$-trimethoxykaempferol and biochanin bonded to the active site of the receptor molecule (Supplementary Figure S3A). Based on the ligand-receptor interaction (Supplementary Figure S3B), it can be seen that 5,7,4'-trimethoxykaempferol and biochanin interacted with the enzyme forming bonds with residues ASP 203, ARG 526, PHE 450 and residues ARG 526, TRP 406, ASP 443 , HIS 600, respectively. The presence of the hydroxyl/carboxyl groups correspond to the hydrogen bond interactions in the protein active site. In the case of Biochanin (Supplementary Figure S3B (Right)), one of the hydroxyl groups corresponds with the hydrogen bond donor to the binding site residue ASP 443, whereas carboxyl group, acted as a hydrogen bond donor to the residue ARG 526. The hydroxyl group of 5,7,4'trimethoxykaempferol (Supplementary Figure S3B (Left)), acted as a hydrogen bond donor to the residue ASP 203 and carboxyl group to the residue ARG 526.

\section{DISCUSSION}

The cost of diabetes treatment is of tremendous concern, especially in developing countries, battling with poor economic growth and other non-communicable diseases. This is responsible for the high diabetic mortality rate in Africa, despite the low occurrence of diabetes compared to the developed world (WHO, 2016). This has led to the search and/or development of affordable alternative medicine from plant source for the treatment and management of diabetes. The use of medicinal plants for healing is part of most African traditions, which is gaining much attention. In this study, we investigated the antidiabetic properties of $C$. volubile leaves and its fractions as well as the compounds that may be responsible for the activity.
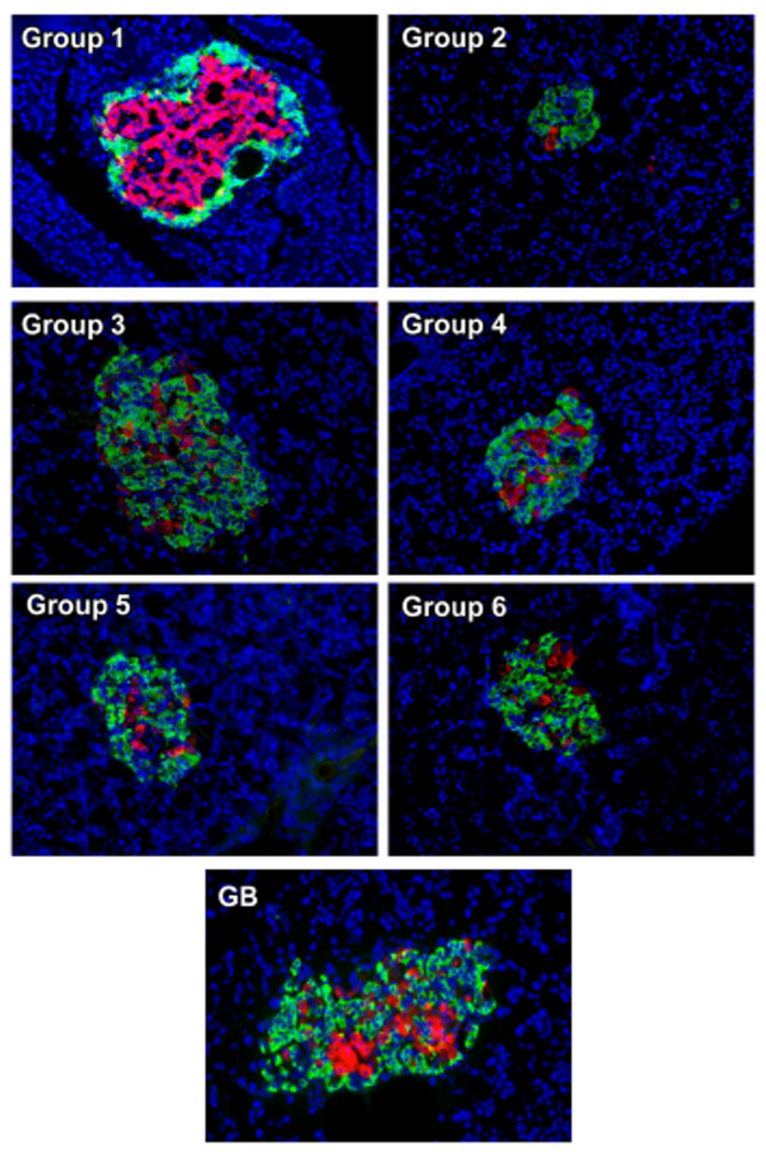

FIGURE 6 | Immunohistochemical analysis of insulin (red) and glucagon (green) in pancreatic islets of experimental groups. Nuclei are counter-stained with DAPI (b/ue). Magnification ×20. Group 1: normal control; Group 2: diabetic control; Group 3: diabetic rats + crude extract; Group 4: diabetic rats + dichloromethane fraction; Group 5: diabetic rats + butanol fraction;

Group 6: diabetic rats + aqueous fraction; GB: diabetic rats + glibenclamide

In vitro inhibition of intestinal $\alpha$-glucosidase has been demonstrated as a means of screening antidiabetic properties of natural products and developed drugs (Ademiluyi and Oboh, 2012; Erukainure et al., 2017a). Its inhibition causes delay and prolong carbohydrate digestion, thus reducing the rate of glucose absorption (Sun et al., 2015). In consequence, the significant inhibition by the DCM, BuOH and aqueous fractions of $C$. volubile portrays an antidiabetic potential.

To select the best effective dose, we performed acute blood glucose lowering effects of $\mathrm{MeOH}, \mathrm{DCM}, \mathrm{BuOH}$ and aqueous fractions of $C$. volubile on diabetic rats. The acute blood glucose lowering data suggests that treatment with $400 \mathrm{mg} / \mathrm{kg}$ bw are more effective, Therefore, $400 \mathrm{mg} / \mathrm{kg}$ bw was utilized as the dose for the chronic experiments.

The relationship between obesity and T2D is well documented and has been attributed to progressive decline in insulin secretion leading to concomitant rise in insulin resistance (Golay and Ybarra, 2005). Insulin resistance is the major metabolic abnormality in T2D (Monzillo and Hamdy, 2003). 


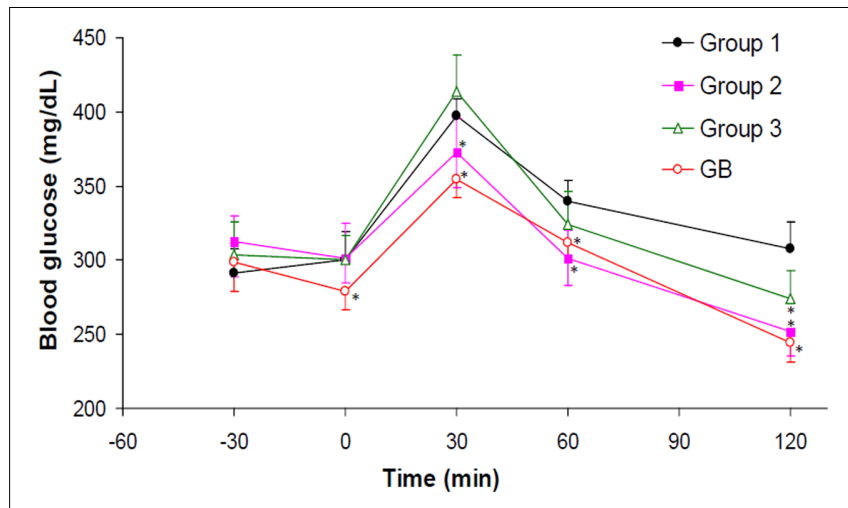

FIGURE 7 | Oral Glucose Tolerance Test (OGTT) of experimental groups. Data $=$ mean $\pm S D ; n=6$. *Values are significantly $(p<0.05)$ different compared to group 1. Group 1: diabetic control (distilled water); Group 2: diabetic rats + crude extract; Group 3: diabetic rats + dichloromethane fraction; GB: diabetic rats + glibenclamide.

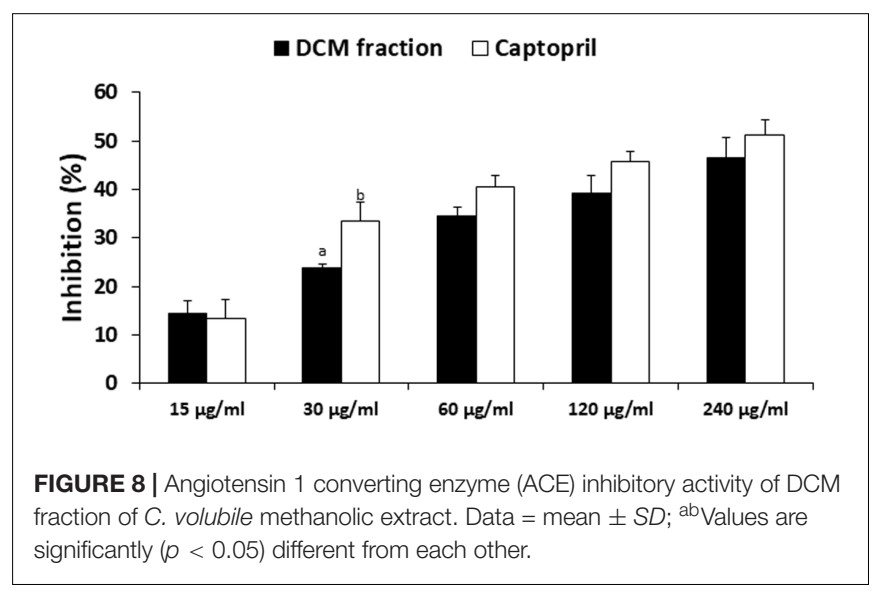

If left unchecked, it will lead to pancreatic $\beta$-cell dysfunction thereby causing chronic hyperglycemia and dyslipidemia (Adiels et al., 2008) normally found in the non-obese type 2 diabetic conditions. This corresponds to the increased weight gain (Figure 2A), high blood glucose level (Figure 2B), depleted serum insulin level and $\beta$-cell function (Figure 2C) in the untreated diabetic rats (group 2). These were significantly $(p<0.05)$ reversed to near normal notably in diabetic rats treated with DCM fractions (group 4) and GB treated rats, indicating an antidiabetic effect which can be attributed to the synergetic effect of the isolated compounds: biochanin and 5,7,4'-trimethoxykaempferol. Their strong binding affinity and molecular interaction on docking with $\alpha$-glucosidase (Supplementary Figures S3A,B) indicates a strong inhibitory effect which corroborates the high inhibitory activity of the fraction on the carbohydrate catabolic enzyme (Figure 1). The impaired glucose intolerance by DCM fraction (Figure 7) further portrays an improved insulin secretion, sensitivity and $\beta$-cell function (Stumvoll et al., 2000; Yeckel et al., 2004). Thus, portraying an antidiabetic property of the fraction. This corresponds to our previous report on the ability of the ethyl

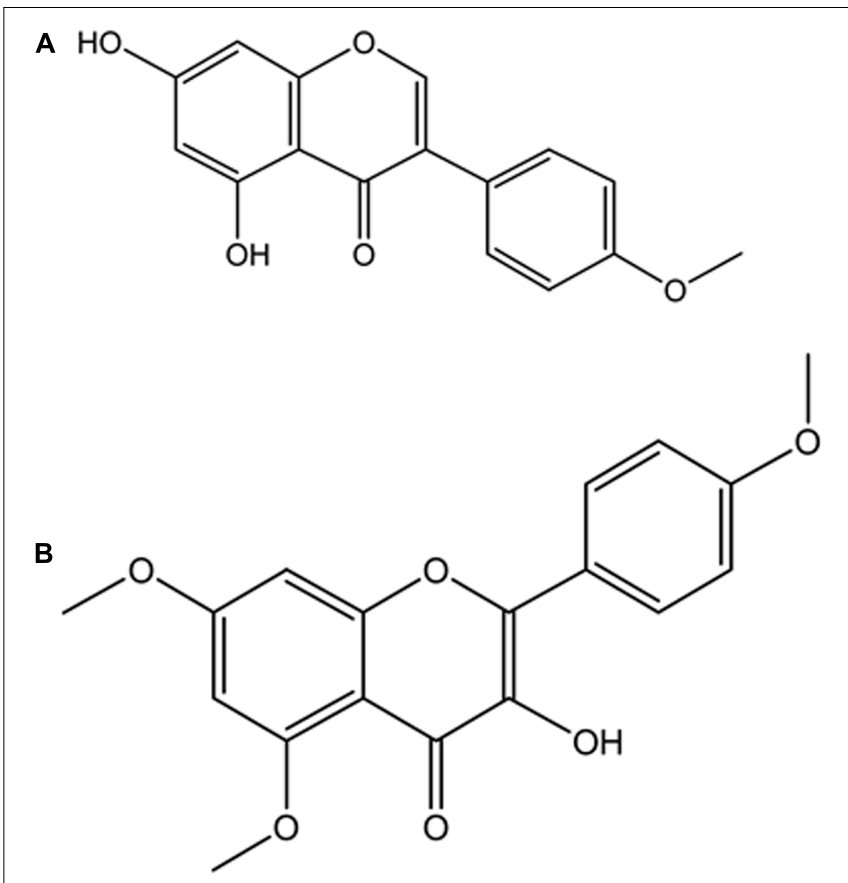

FIGURE 9 | Isolated compounds from DCM fraction of $C$. volubile methanolic extract. (A) 4'-methoxj'-5,7-dihydroxy isonnvone (Biochanin); (B) 5,7,4'-trimethoxykaempferol.

TABLE 2 | Predicted toxicity and drug likeness of isolated flavones.

\begin{tabular}{|c|c|c|}
\hline Parameters & Biochanin & $5,7,4^{\prime}$-trimethoxykaempferol \\
\hline Gl absorption & High & High \\
\hline BBB permeate & Yes & No \\
\hline P-gp substrate & No & No \\
\hline CYP1A2 inhibitor & Yes & Yes \\
\hline CYP2C19 inhibitor & No & No \\
\hline CYP2C9 inhibitor & Yes & No \\
\hline CYP2D6 inhibitor & Yes & Yes \\
\hline CYP3A4 inhibitor & Yes & Yes \\
\hline Log Kp (skin permeation) & $-6.66 \mathrm{~cm} / \mathrm{s}$ & $-5.91 \mathrm{~cm} / \mathrm{s}$ \\
\hline Oral LD 50 (rats) & 3919 mg/Kg & $2500 \mathrm{mg} / \mathrm{Kg}$ \\
\hline Toxicity class & 5 & 5 \\
\hline
\end{tabular}

acetate fraction of C. volubile methanolic extract to reduce blood glucose level and improve insulin secretion and $\beta$-cell function in type 2 diabetic rats (Erukainure et al., 2017a).

The elevated levels of serum cholesterol, triglyceride, LDL-C and vLDL-C as well as decreased HDL-C level in the untreated diabetic rats (group 2) indicates an occurrence of dyslipidemia (Figure 3). Insulin resistance alters lipid metabolism in T2D, rendering the lipoproteins pathogenic which has been implicated in the progression of T2D complications (Vijayaraghavan, 2010; Erukainure et al., 2013). This alteration also corresponds to the increased weight gain in the untreated diabetic rats (Figure 2A) and can be attributed to the depleted serum insulin level and $\beta$-cell function (Figures 2B,C). The depleted levels of serum cholesterol, triglyceride, LDL-C and vLDL-C after treatment with 
the crude extract and fractions therefore indicate a therapeutic anti-dyslipidemic effect.

The depleted GSH level as well as decreased SOD and catalase activities (Table 1) in the serum and pancreatic tissues of untreated diabetic rats (group 2) indicates an occurrence of oxidative stress. The role of oxidative stress in the progression and pathogenesis of T2D and its complications has been attributed to the extremely low level of antioxidants in the pancreatic $\beta$-cells (Robertson and Harmon, 2007). The levels of SOD and catalase in pancreatic tissue are 50 and $1 \%$, respectively, compared to that of hepatic tissue (Pi et al., 2010). The decreased catalase activity implies an increased production of hydroxyl radical ('OH) from accumulated $\mathrm{H}_{2} \mathrm{O}_{2}$ due to the depleted enzyme level (Kanias and Acker, 2010). OH then attacks the membrane lipid thereby initiating a peroxidative chain reaction, with MDA and 4-Hydroxynonenal (4-HNE) as the usual end-products (Aslan et al., 2000; Kanias and Acker, 2010). This corresponds to the high MDA level in the untreated diabetic rats (group 2), indicating an occurrence of lipid peroxidation. The reversed GSH and MDA levels as well increased SOD and catalase activities therefore portray an antioxidative protective effect. The high activity in the DCM fraction treated diabetic rats can be attributed to the isolated flavonoids (Figure 9). The antioxidative activities of flavonoids are well documented and have been attributed to their fifteen-carbon skeleton consisting of two benzene rings connected by a heterocyclic pyrane ring (Kumar and Pandey, 2013; Vinayagam and Xu, 2015).

Hepatotoxicity and nephrotoxicity have been reported as major complications of T2D owing to insulin resistance and oxidative damage (Vozarova et al., 2002). They are characterized by increased serum levels of hepatic and renal enzymes due to inflammation of the tissues (Erukainure et al., 2015). The increased levels in the diabetic rats (group 2) portrays incidences of hepatotoxicity and nephrotoxicity. The decreased levels after treatment with the crude extract and fractions indicates a protective effect in diabetics and compared favorably with GB treated group. However, the increased AST and ALT levels in diabetic rats treated with the aqueous fraction (group 6) indicates a hepatotoxic effect (Figure 4).

Elevated pancreatic $\mathrm{Ca}^{2+}$ level has been associated with increased insulin secretion via exocytosis of insulin granules (Rorsman et al., 2012). $\mathrm{Ca}^{2+}$ alterations may impair insulin signal transduction, thereby contributing to peripheral insulin resistance (Pittas et al., 2007). The elevated levels in the treated diabetic rats (Figure 5), particularly group 4 corroborates the elevated serum insulin levels (Figure 2C). This may be attributed to an increased ATP: ADP ratio, causing depolarization of the pancreatic $\beta$-cell due to potassium efflux (Shukla et al., 2012). This triggers the opening voltage - calcium channels, allowing an influx of $\mathrm{Ca}^{2+}$ into the cell (Pittas et al., 2007; Shukla et al., 2012). Flavonoids have been reported for their ability to open the voltage - gated calcium channels (Kim et al., 2004; Saponara et al., 2008; Scholz et al., 2010), which may be responsible for the increased pancreatic $\mathrm{Ca}^{2+}$ levels in diabetic rats treated with DCM fraction.

The uneven distribution of $\alpha$ - and $\beta$-cells (Figure 6), with the $\beta$-cells less in pancreatic tissues of untreated diabetic rats (group 2) corroborates the depleted serum insulin level and pancreatic $\beta$-cell function as well as increased blood glucose level (Figures 2B,C). The deteriorated $\beta$-cells indicates a truncated secretion of insulin typical in T2D. The inappropriate increased $\alpha$-cells portrays an increased $\alpha$-cell function and concomitant secretion of glucagon, leading to hyperglycemia (Hafizur et al., 2011, 2017; Godoy-Matos, 2014). Increased hyperglycemia has been implicated in the progression as well as induction and pathogenesis of oxidative stress in type 2 diabetes and may be responsible for the depleted antioxidant activities (Table 1) (Constantino et al., 2013; Tiwari et al., 2013). The increased $\beta$-cells and evenly distributed $\alpha$-cells in the treated groups depict an improved $\beta$-cell function and hypoglycemic activity, respectively, which also compares favorably with the GB treated rats. Thereby corroborating the increased serum insulin and reduced blood glucose levels (Figures 2B,C), as well as improved antioxidant activities (Table 1).

Prevalence of the co-existence of diabetes and hypertension has been reported, with $75 \%$ of diabetic patients hypertensive (Kaplan, 1987; Grossman and Grossman, 2017). This has been attributed to insulin resistance induced stimulation of the angiotensin 1 receptor (Tuck et al., 2004). Stimulation of the angiotensin 1 receptor activates the angiotensin 1 converting enzyme (ACE), thereby causing an elevated level of angiotensin II which is vasoconstrictive (Oboh et al., 2017). The dosedependent inhibition of ACE by the DCM fraction (Figure 8), therefore indicates a protective effect against hypertension. Several studies have reported the anti-hypertensive properties of flavonoids (Loizzo et al., 2007; Guerrero et al., 2012; Shafaei et al., 2016), which is also reflected in the strong binding affinity and molecular interactions of the isolated compounds (biochanin and 5,7,4'-trimethoxykaempferol) on docking with the crystal structure of Human Angiotensin Converting Enzyme (PDB ID: 1O86) (Supplementary Figures S2A,B). This correlates with the increased pancreatic $\beta$-cell and serum insulin level as ACE inhibitors have been shown to be not just therapeutic against hypertension but also reduces the risk of type 2 diabetes and its complications (Abuissa et al., 2005; Ramos-Nino and Blumen, 2009).

The toxicity and safety of medicinal plants remains a huge concern to health practitioners particularly modulation of cytochrome P450 enzyme family (CYP) and P-glycoprotein (P-gp). CYPs are the most recognized enzymes involved in drug metabolism, thus their modulation can have therapeutic consequences (Ondieki et al., 2017). The predicted inhibition of CYP1A2, CYP2C9, CYP2D6, and CYP3A4 by biochanin and 5,7,4'-trimethoxykaempferol (Table 1), therefore suggests an influential role in drug metabolism. CYP1A2 is involved in the metabolism of caffeine and has been reported in type 2 diabetes patients on caffeine therapy and/or consumes coffee (Urry et al., 2016). Its predicted inhibition by the compounds indicates a low metabolism of caffeine when co-administered, thereby leading to high concentration of caffeine with toxic consequence (high-dose effect). Likewise, co-administration of the compounds with antidiabetic drugs metabolized by the other CYPs (CYP2D6 and CYP3A4) will also elicit an over dose effect of the drugs. Inhibition of CYP2C9 by biochanin may 
be advantageous, as CYP2C9 metabolizes linoleic acid to the toxic epoxides, leukotoxin and isoleukotoxin which have been implicated in multiple organ failure and acute respiratory distress (Spector and Kim, 2015). The ability of biochanin to permeate $\mathrm{BBB}$ is of tremendous advantage, as it suggests a therapeutic effect against glucose - neurotoxicity. The predicted high GI absorption of the compounds can be attributed to the lipophilic properties of flavonoids, making them able to cross the lipid membrane (Kumar and Pandey, 2013; Echeverría et al., 2017). The predicted oral lethal dose $\left(\mathrm{LD}_{50}\right)$ and toxicity class of the compounds indicates its safety when orally ingested, this correlates with other predicted toxicity of isolated compounds from $C$. volubile leaves (Erukainure et al., 2017a,b,c).

\section{CONCLUSION}

These results portray the therapeutic effect of $C$. volubile leaves against type 2 diabetes, with the DCM fraction being the most potent. The synergetic attenuation of pancreatic redox imbalance, dyslipidemia; modulation of glucose and insulin homeostasis; as well as improved pancreatic $\beta$-cell distribution and function suggests possible antidiabetic mechanisms. This is further evident by the molecular interaction of the isolated flavones from the DCM fraction with $\alpha$-glucosidase in silico. Additionally, the molecular interaction of these flavones with ACE-1 and the observed inhibitory effect on this enzyme suggests antihypertensive potentials of this fraction, which can be further investigated in type 2 diabetic models. However, modulation of CYPs 1A2, 2C9, 2D6, and 3A4 by the flavones suggests caution in usage with other prescribed drugs metabolized by these enzymes. A further study is being proposed on the comparative antidiabetic properties of the isolated compounds with other standard antidiabetic drugs, particularly metformin and glibenclamide in type 2 diabetic models.

\section{AUTHOR CONTRIBUTIONS}

OE, RH, MC: designed the project. OE, RH, NK: performed antidiabetic experiments. OE and AM: performed $\mathrm{Ca}^{2+}$ level. $\mathrm{OE}, \mathrm{MC}$, and OA: isolated and elucidated the pure compounds. $\mathrm{OA}, \mathrm{PB}$, and RP: performed in silico studies. CC, MI, and EA:

\section{REFERENCES}

Abuissa, H., Jones, P. G., Marso, S. P., and O’Keefe, J. H. (2005). Angiotensinconverting enzyme inhibitors or angiotensin receptor blockers for prevention of type 2 diabetes. J. Am. Coll. Cardiol. 46, 821-826. doi: 10.1016/j.jacc.2005. 05.051

Adefegha, S. A., and Oboh, G. (2016). Antioxidant and inhibitory properties of Clerodendrum volubile leaf extracts on key enzymes relevant to non-insulin dependent diabetes mellitus and hypertension. J. Taibah Univ. Sci. 10, 521-533. doi: 10.1016/j.jtusci.2015.10.008

Ademiluyi, A. O., and Oboh, G. (2012). Phenolic-rich extracts from selected tropical underutilized legumes inhibit $\alpha$-amylase, $\alpha$-glucosidase, and angiotensin I converting enzyme in vitro. J. Basic Clin. Physiol. Pharmacol. 23, 17-25. doi: 10.1515/jbcpp-2011-0005 performed ACE inhibition. $\mathrm{OE}, \mathrm{RH}, \mathrm{MI}, \mathrm{PB}$, and $\mathrm{CC}$ wrote the manuscript. All authors revised the manuscript.

\section{ACKNOWLEDGMENTS}

OE acknowledges The World Academy of Sciences (TWAS) for 2012 ICCBS-TWAS fellowship at the H.E.J. Research Institute of Chemistry, ICCBS, University of Karachi, Karachi, Pakistan. OA acknowledges 2015 TWAS-DFG Postdoctoral Fellowship to Structural Bioinformatics Group, Charité - University Medicine Berlin, Berlin, Germany.

\section{SUPPLEMENTARY MATERIAL}

The Supplementary Material for this article can be found online at: https://www.frontiersin.org/articles/10.3389/fphar. 2018.00008/full\#supplementary-material

FIGURE S1 | Acute effects of crude extract (MeOH), dichloromethane fraction (DCM), butanol fraction (BuOH) and aqueous fraction (aqueous) on blood glucose of diabetic rats. Values are means $\pm S D(n=5)$. Control: non-diabetic control rats; $\mathrm{Db}$ : diabetic rats treated with saline only; Crude- $200 \mathrm{mg} / \mathrm{kg}$, and

Crude-400 mg/kg: diabetic rats treated with $\mathrm{MeOH}$ extract of 200 and $400 \mathrm{mg} / \mathrm{kg}$ bw; DCM-200 mg/kg, and DCM-400 mg/kg: diabetic rats treated with DCM fraction of 200 and $400 \mathrm{mg} / \mathrm{kg}$; BuOH-200 mg/kg, and BuOH-400 mg/kg: diabetic rats treated with $\mathrm{BuOH}$ fraction of 200 and $400 \mathrm{mg} / \mathrm{kg} \mathrm{bw}$; aqueous-200 mg/kg, and aqueous-400 mg/kg: diabetic rats treated with aqueous fraction of 200 and $400 \mathrm{mg} / \mathrm{kg}$ bw; GB-5mg/kg: diabetic rats treated with glibenclamide $5 \mathrm{mg} / \mathrm{kg}$ bw. ${ }^{*} p<0.05,{ }^{* *} p<0.01$, ${ }^{* * *} p<0.001$, compared to their respective $0-h$ values.

FIGURE S2 | (A) Binding orientation and interaction of the original ligand lisinopril (in magenta) and the docked compounds 5,7,4' -trimethoxykaempferol (in blue) and Biochanin (in orange) into the active site of the ACE enzyme. (B) Ligand-protein interaction diagram: 5,7,4'-trimethoxykaempferol (Left) and Biochanin (Right) interacts with the protein ACE, respectively, via hydrogen bonds (shown in blue arrow) and $\pi$ interactions (shown as orange lines) with the participating $\pi$ systems and hydrophobic contacts.

FIGURE S3 | (A) Binding orientation and interaction of the original ligand acarbose (in magenta) and the docked compounds 5,7,4' -trimethoxykaempferol (in blue) and Biochanin (in orange) into the active site of the Human Maltase-Glucoamylase enzyme. (B) Ligand-protein interaction diagram: 5,7,4'-trimethoxykaempferol (Left) and Biochanin (Right) interacts with the protein Human Maltase-Glucoamylase, respectively, via hydrogen bonds (shown in blue arrow) and $\pi$ interactions (shown as orange lines) with the participating $\pi$ systems and hydrophobic contacts.
Adiels, M., Olofsson, S.-O., Taskinen, M.-R., and Borén, J. (2008). Overproduction of very low-density lipoproteins is the hallmark of the dyslipidemia in the metabolic syndrome. Arterioscler. Thromb. Vasc. Biol. 28, 1225-1236. doi: 10.1161/ATVBAHA.107.160192

Aslan, M., Thornley-Brown, D., and Freeman, B. A. (2000). Reactive species in sickle cell disease. Ann. N. Y. Acad. Sci. 899, 375-391. doi: 10.1111/j.1749-6632. 2000.tb06201.x

Banerjee, P., Erehman, J., Gohlke, B.-O., Wilhelm, T., Preissner, R., and Dunkel, M. (2014). Super Natural II-a database of natural products. Nucleic Acids Res. 43, D935-D939. doi: 10.1093/nar/gku886

Burkill, H. M. (1985). The Useful Plants of West Tropical Africa, 2nd Edn, Vol. 1. London: Kew, Royal Botanic Gardens.

Cerf, M. E. (2013). Beta cell dysfunction and insulin resistance. Front. Endocrinol. 4:37. doi: $10.3389 /$ fendo.2013.00037 
Chance, B., and Maehly, A. (1955). Assay of catalases and peroxidases. Methods Enzymol. 2, 764-775. doi: 10.1016/S0076-6879(55)02300-8

Chikezie, P., Ojiako, O., and Nwufo, K. (2015). Overview of anti-diabetic medicinal plants: the Nigerian research experience. J. Diabetes Metab. 6:546. doi: 10.4172/ 2155-6156.1000546

Chowdhury, P., and Soulsby, M. (2002). Lipid peroxidation in rat brain is increased by simulated weightlessness and decreased by a soy-protein diet. Ann. Clin. Lab. Sci. 32, 188-192.

Constantino, M. I., Molyneaux, L., Limacher-Gisler, F., Al-Saeed, A., Luo, C., $\mathrm{Wu}, \mathrm{T}$., et al. (2013). Long-term complications and mortality in young-onset diabetes. Diabetes Care 36, 3863-3869. doi: 10.2337/dc12-2455

Daina, A., Michielin, O., and Zoete, V. (2017). SwissADME: a free web tool to evaluate pharmacokinetics, drug-likeness and medicinal chemistry friendliness of small molecules. Sci. Rep. 7:42717. doi: 10.1038/srep42717

Drwal, M. N., Banerjee, P., Dunkel, M., Wettig, M. R., and Preissner, R. (2014). ProTox: a web server for the in silico prediction of rodent oral toxicity. Nucleic Acids Res. 42, W53-W58. doi: 10.1093/nar/gku401

Du, X., Bai, Y., Liang, H., Wang, Z., Zhao, Y., Zhang, Q., et al. (2006). Solvent effect in ${ }^{1} \mathrm{H}$ NMR spectra of $3^{\prime}$-hydroxy-4' -methoxy isoflavonoids from Astragalus membranaceus var. mongholicus. Magn. Reson. Chem. 44, 708-712. doi: $10.1002 / \mathrm{mrc} .1806$

Echeverría, J., Opazo, J., Mendoza, L., Urzúa, A., and Wilkens, M. (2017). Structure-activity and lipophilicity relationships of selected antibacterial natural flavones and flavanones of Chilean flora. Molecules 22:608. doi: 10.3390/ molecules22040608

Ellman, G. L. (1959). Tissue sulfhydryl groups. Arch. Biochem. Biophys. 82, 70-77. doi: 10.1016/0003-9861(59)90090-6

Erukainure, O. L., Ebuehi, O. A., Adeboyejo, F. O., Okafor, E. N., Muhammad, A., and Elemo, G. N. (2013). Fiber-enriched biscuit enhances insulin secretion, modulates $\beta$-cell function, improves insulin sensitivity, and attenuates hyperlipidemia in diabetic rats. PharmaNutrition 1, 58-64. doi: 10.1016/j. phanu.2013.02.001

Erukainure, O. L., Ebuehi, O. A., Adeboyejo, F. O., Oladunmoye, O. O., Aliyu, M., Obode, O. C., et al. (2015). Short-term feeding of fibre-enriched biscuits: protective effect against hepatotoxicity in diabetic rats. Biochem. Res. Int. 2015:868937. doi: 10.1155/2015/868937

Erukainure, O. L., Ebuehi, O. A., Choudhary, I. M., Adhikari, A., Hafizur, R. M., Perveen, S., et al. (2014). Iridoid glycoside from the leaves of Clerodendrum volubile beauv. shows potent antioxidant activity against oxidative stress in rat brain and hepatic tissues. J. Diet. Suppl. 11, 19-29. doi: 10.3109/19390211.2013. 859213

Erukainure, O. L., Hafizur, R. M., Choudhary, M. I., Adhikari, A., Mesaik, A. M., Atolani, O., et al. (2017a). Anti-diabetic effect of the ethyl acetate fraction of Clerodendrum volubile: protocatechuic acid suppresses phagocytic oxidative burst and modulates inflammatory cytokines. Biomed. Pharmacother. 86, 307-315. doi: 10.1016/j.biopha.2016.12.035

Erukainure, O. L., Mesaik, A. M., Muhammad, A., Chukwuma, C. I., Manhas, N., Singh, P., et al. (2016a). Flowers of Clerodendrum volubile exacerbate immunomodulation by suppressing phagocytic oxidative burst and modulation of COX-2 activity. Biomed. Pharmacother. 83, 1478-1484. doi: 10.1016/j.biopha. 2016.09.002

Erukainure, O. L., Mesaik, M. A., Atolani, O., Muhammad, A., Chukwuma, C. I., and Islam, M. S. (2017b). Pectolinarigenin from the leaves of Clerodendrum volubile shows potent immunomodulatory activity by inhibiting $\mathrm{T}$ - cell proliferation and modulating respiratory oxidative burst in phagocytes. Biomed. Pharmacother. 93, 529-535. doi: 10.1016/j.biopha.2017.06.060

Erukainure, O. L., Zaruwa, M. Z., Choudhary, M. I., Naqvi, S. A., Ashraf, N., Hafizur, R. M., et al. (2016b). Dietary fatty acids from leaves of Clerodendrum volubile induce cell cycle arrest, downregulate matrix metalloproteinase-9 expression, and modulate redox status in human breast cancer. Nutr. Cancer 68, 634-645. doi: 10.1080/01635581.2016.1156714

Erukainure, O. L., Zaruwa, M. Z., Mesaik, A. M., Muhammad, A., Adoga, J. O., Ogunyemi, I. O., et al. (2017c). Suppression of phagocytic oxidative burst, cytotoxic effect, and computational prediction of oral toxicity of dietary fatty acids of Clerodendrum volubile stem. Comp. Clin. Pathol. 26, 663-671. doi: 10.1007/s00580-017-2438-y

Fokialakis, N., Alexi, X., Aligiannis, N., Siriani, D., Meligova, A. K., Pratsinis, H., et al. (2012). Ester and carbamate ester derivatives of Biochanin A: synthesis and in vitro evaluation of estrogenic and antiproliferative activities. Bioorg. Med. Chem. 20, 2962-2970. doi: 10.1016/j.bmc.2012.03.012

Friedewald, W. T., Levy, R. I., and Fredrickson, D. S. (1972). Estimation of the concentration of low-density lipoprotein cholesterol in plasma, without use of the preparative ultracentrifuge. Clin. Chem. 18, 499-502.

Godoy-Matos, A. F. (2014). The role of glucagon on type 2 diabetes at a glance. Diabetol. Metab. Syndr. 6:91. doi: 10.1186/1758-5996-6-91

Golay, A., and Ybarra, J. (2005). Link between obesity and type 2 diabetes. Best Pract. Res. Clin. Endocrinol. Metab. 19, 649-663. doi: 10.1016/j.beem.2005. 07.010

Grossman, A., and Grossman, E. (2017). Blood pressure control in type 2 diabetic patients. Cardiovasc. Diabetol. 16:3. doi: 10.1186/s12933-016-0485-3

Guerrero, L., Castillo, J., Quiñones, M., Garcia-Vallvé, S., Arola, L., Pujadas, G., et al. (2012). Inhibition of angiotensin-converting enzyme activity by flavonoids: structure-activity relationship studies. PLOS ONE 7:e49493. doi: 10.1371/journal.pone.0049493

Hafizur, R. M., Kabir, N., and Chishti, S. (2011). Modulation of pancreatic $\beta$-cells in neonatally streptozotocin-induced type 2 diabetic rats by the ethanolic extract of Momordica charantia fruit pulp. Nat. Prod. Res. 25, 353-367. doi: 10.1080/ 14786411003766904

Hafizur, R. M., Kabir, N., and Chishti, S. (2012). Asparagus officinalis extract controls blood glucose by improving insulin secretion and $\beta$-cell function in streptozotocin-induced type 2 diabetic rats. Br. J. Nutr. 108, 1586-1595. doi: $10.1017 /$ S0007114511007148

Hafizur, R. M., Momin, S., and Fatima, N. (2017). Prevention of advanced glycation end-products formation in diabetic rats through beta-cell modulation by Aegle marmelos. BMC Complement. Altern. Med. 17:227. doi: 10.1186/s12906-0171743-y

International Diabetes Federation [IDF] (2015). IDF Diabetes Atlas. Available at: http://www.diabetesatlas.org [accessed July 8, 2016].

Kakkar, P., Das, B., and Viswanathan, P. (1984). A modified spectrophotometric assay of superoxide dismutase. Indian J. Biochem. Biophys. 21, 130-132.

Kanias, T., and Acker, J. P. (2010). Biopreservation of red blood cells-the struggle with hemoglobin oxidation. FEBS J. 277, 343-356. doi: 10.1111/j.1742-4658. 2009.07472.x

Kaplan, N. M. (1987). Treating hypertension in the diabetic patient. Clin. Diabetes 5, 25-34.

Kim, H. J., Yum, K. S., Sung, J.-H., Rhie, D.-J., Kim, M.-J., Hahn, S. J., et al. (2004). Epigallocatechin-3-gallate increases intracellular $\left[\mathrm{Ca}^{2+}\right]$ in $\mathrm{U} 87$ cells mainly by influx of extracellular $\mathrm{Ca}^{2+}$ and partly by release of intracellular stores. Naunyn Schmiedebergs Arch. Pharmacol. 369, 260-267.

Kitamura, M., Okuyama, M., Tanzawa, F., Mori, H., Kitago, Y., Watanabe, N., et al. (2008). Structural and functional analysis of a glycoside hydrolase family 97 enzyme from Bacteroides thetaiotaomicron. J. Biol. Chem. 283, 36328-36337. doi: 10.1074/jbc.M806115200

Kumar, S., and Pandey, A. K. (2013). Chemistry and biological activities of flavonoids: an overview. Sci. World J. 2013:162750. doi: 10.1155/2013/ 162750

Loizzo, M. R., Said, A., Tundis, R., Rashed, K., Statti, G. A., Hufner, A., et al. (2007) Inhibition of angiotensin converting enzyme (ACE) by flavonoids isolated from Ailanthus excelsa (Roxb) (Simaroubaceae). Phytother. Res. 21, 32-36. doi: 10.1002/ptr.2008

Lowry, O. H., Rosebrough, N. J., Farr, A. L., and Randall, R. J. (1951). Protein measurement with the Folin phenol reagent. J. Biol. Chem. 193, 265-275.

Monzillo, L. U., and Hamdy, O. (2003). Evaluation of insulin sensitivity in clinical practice and in research settings. Nutr. Rev. 61, 397-412. doi: 10.1301/nr.2003. dec.397-412

Noor, F., Rahman, H. M., Abdul, H., Shakil, A., Maliha, N., and Nurul, K. (2017). Ellagic acid in Emblica officinalis exerts anti-diabetic activity through the action on $\beta$-cells of pancreas. Eur. J. Nutr. 56, 591-601. doi: 10.1007/s00394-0151103-y

Oboh, G., and Ademosun, A. O. (2011). Shaddock peels (Citrus maxima) phenolic extracts inhibit $\alpha$-amylase, $\alpha$-glucosidase and angiotensin I-converting enzyme activities: a nutraceutical approach to diabetes management. Diabetes Metab. Syndr. 5, 148-152. doi: 10.1016/j.dsx.2012.02.008

Oboh, G., Akinyemi, A. J., and Ademiluyi, A. O. (2013). Inhibitory effect of phenolic extract from garlic on angiotensin-1 converting enzyme and cisplatin induced lipid peroxidation-in vitro. Int. J. Biomed. Sci. 9, 98-106. 
Oboh, G., Olasehinde, T. A., and Ademosun, A. O. (2017). Inhibition of enzymes linked to Type-2 diabetes and hypertension by essential oils from peels of orange and lemon. Int. J. Food Prop. 20, S586-S594. doi: 10.1080/10942912. 2017.1303709

Ondieki, G., Nyagblordzro, M., Kikete, S., Liang, R., Wang, L., and He, X. (2017). Cytochrome P450 and P-glycoprotein-mediated interactions involving African herbs indicated for common noncommunicable diseases. Evid. Based Complement. Altern. Med. 2017:2582463. doi: 10.1155/2017/2582463

Patel, D., Prasad, S., Kumar, R., and Hemalatha, S. (2012). An overview on antidiabetic medicinal plants having insulin mimetic property. Asian Pac. J. Trop. Biomed. 2, 320-330. doi: 10.1016/S2221-1691(12)60032-X

Pi, J., Zhang, Q., Fu, J., Woods, C. G., Hou, Y., Corkey, B. E., et al. (2010). ROS signaling, oxidative stress and Nrf2 in pancreatic beta-cell function. Toxicol. Appl. Pharmacol. 244, 77-83. doi: 10.1016/j.taap.2009.05.025

Pittas, A. G., Lau, J., Hu, F. B., and Dawson-Hughes, B. (2007). The role of vitamin $\mathrm{D}$ and calcium in type 2 diabetes. A systematic review and meta-analysis. J. Clin. Endocrinol. Metab. 92, 2017-2029. doi: 10.1210/jc.2007-0298

Prentki, M., and Nolan, C. J. (2006). Islet $\beta$ cell failure in type 2 diabetes. J. Clin. Invest. 116, 1802-1812. doi: 10.1172/JCI29103

Ramos-Nino, M. E., and Blumen, S. R. (2009). Benefits of ACE inhibitors in diabetes. Clin. Med. Ther. 1, 1041-1051. doi: 10.4137/CMT.S2027

Ramsay, K. S. T., Wafo, P., Ali, Z., Khan, A., Oluyemisi, O. O., Marasini, B. P., et al. (2012). Chemical constituents of Stereospermum acuminatissimum and their urease and $\alpha$-chymotrypsin inhibitions. Fitoterapia 83, 204-208. doi: 10.1016/j.fitote.2011.10.014

Robertson, R. P., and Harmon, J. S. (2007). Pancreatic islet $\beta$-cell and oxidative stress: the importance of glutathione peroxidase. FEBS Lett. 581, 3743-3748. doi: 10.1016/j.febslet.2007.03.087

Rorsman, P., Braun, M., and Zhang, Q. (2012). Regulation of calcium in pancreatic $\alpha$-and $\beta$-cells in health and disease. Cell Calcium 51, 300-308. doi: 10.1016/j. ceca.2011.11.006

Saeed, N., Khan, M. R., and Shabbir, M. (2012). Antioxidant activity, total phenolic and total flavonoid contents of whole plant extracts Torilis leptophylla L. BMC Complement. Altern. Med. 12:221. doi: 10.1186/1472-688212-221

Saponara, S., Sgaragli, G., and Fusi, F. (2008). Quercetin antagonism of Bay K 8644 effects on rat tail artery L-type $\mathrm{Ca}^{2+}$ channels. Eur. J. Pharmacol. 598, 75-80. doi: 10.1016/j.ejphar.2008.08.016

Scholz, E. P., Zitron, E., Katus, H. A., and Karle, C. A. (2010). Cardiovascular ion channels as a molecular target of flavonoids. Cardiovasc. Ther. 28, e46-e52. doi: 10.1111/j.1755-5922.2010.00212.x

Shafaei, A., Sultan Khan, M. S., Fa Aisha, A., Abdul Majid, A. M. S., Hamdan, M. R., Mordi, M. N., et al. (2016). Flavonoids-rich Orthosiphon stamineus extract as new candidate for angiotensin I-converting enzyme inhibition: a molecular docking study. Molecules 21:1500. doi: 10.3390/molecules2111 1500

Shukla, A., Priyadarshi, S., and Qamar, I. (2012). Involvement of calcium and vitamin C in Type 2 diabetes. IOSR J. Pharm. 2, 9-20. doi: 10.9790/30130210920
Spector, A. A., and Kim, H.-Y. (2015). Cytochrome P 450 epoxygenase pathway of polyunsaturated fatty acid metabolism. Biochim. Biophys. Acta 1851, 356-365. doi: 10.1016/j.bbalip.2014.07.020

Stumvoll, M., Mitrakou, A., Pimenta, W., Jenssen, T., Yki-Järvinen, H., Van Haeften, T., et al. (2000). Use of the oral glucose tolerance test to assess insulin release and insulin sensitivity. Diabetes Care 23, 295-301. doi: 10.2337/diacare. 23.3.295

Sun, H., Li, Y., Zhang, X., Lei, Y., Ding, W., Zhao, X., et al. (2015). Synthesis, $\alpha$-glucosidase inhibitory and molecular docking studies of prenylated and geranylated flavones, isoflavones and chalcones. Bioorg. Med. Chem. Lett. 25, 4567-4571. doi: 10.1016/j.bmcl.2015.08.059

Tiwari, B. K., Pandey, K. B., Abidi, A., and Rizvi, S. I. (2013). Markers of oxidative stress during diabetes mellitus. J. Biomark. 2013:378790. doi: 10.1155/2013/ 378790

Tuck, M. L., Bounoua, F., Eslami, P., Nyby, M. D., Eggena, P., and Corry, D. B. (2004). Insulin stimulates endogenous angiotensin II production via a mitogen-activated protein kinase pathway in vascular smooth muscle cells. J. Hypertens. 22, 1779-1785. doi: 10.1097/00004872-20040900000023

Urry, E., Jetter, A., and Landolt, H.-P. (2016). Assessment of CYP1A2 enzyme activity in relation to type-2 diabetes and habitual caffeine intake. Nutr. Metab. 13:66. doi: 10.1186/s12986-016-0126-6

Vijayaraghavan, K. (2010). Treatment of dyslipidemia in patients with type 2 diabetes. Lipids Health Dis. 9:144. doi: 10.1186/1476-511X-9-144

Vinayagam, R., and Xu, B. (2015). Antidiabetic properties of dietary flavonoids: a cellular mechanism review. Nutr. Metab. 12:60. doi: 10.1186/s12986-0150057-7

Vozarova, B., Stefan, N., Lindsay, R. S., Saremi, A., Pratley, R. E., Bogardus, C., et al. (2002). High alanine aminotransferase is associated with decreased hepatic insulin sensitivity and predicts the development of type 2 diabetes. Diabetes 51 , 1889-1895. doi: 10.2337/diabetes.51.6.1889

WHO (2016). Global Report on Diabetes. Geneva: World Health Organization.

Yeckel, C. W., Weiss, R., Dziura, J., Taksali, S. E., Dufour, S., Burgert, T. S., et al. (2004). Validation of insulin sensitivity indices from oral glucose tolerance test parameters in obese children and adolescents. J. Clin. Endocrinol. Metab. 89, 1096-1101. doi: 10.1210/jc.2003-031503

Conflict of Interest Statement: The authors declare that the research was conducted in the absence of any commercial or financial relationships that could be construed as a potential conflict of interest.

Copyright (C) 2018 Erukainure, Hafizur, Kabir, Choudhary, Atolani, Banerjee, Preissner, Chukwuma, Muhammad, Amonsou and Islam. This is an open-access article distributed under the terms of the Creative Commons Attribution License (CC BY). The use, distribution or reproduction in other forums is permitted, provided the original author(s) and the copyright owner are credited and that the original publication in this journal is cited, in accordance with accepted academic practice. No use, distribution or reproduction is permitted which does not comply with these terms. 